\title{
INFLUENCE OF INITIATORS ON THE ADHESION PROPERTIES OF BITUMEN MODIFIED BY NATURAL ORIGIN EPOXIDE
}

\author{
Volodymyr Starchevskyy1, ${ }^{\circledR}$, Yurii Hrynchuk ${ }^{1}$, Pavlo Matcipura $^{1}$, \\ Volodymyr Reutskyy ${ }^{1}$
}

https://doi.org/10.23939/chcht15.01.142

\begin{abstract}
The article is presenting a modification of bituminous binder with ecological epoxidized rapeseed oil (BERO) in the presence of the initiator (hardener). Adipic acid (AA), maleic anhydride (MA) and polyethylene polyamine (PEPA) were used as the initiators. The effect of modification temperature and, as well as initiator nature, on the bitumen properties was determined. Bitumen modified with BERO was evaluated by the following indicators: softening temperature, penetration, ductility, and adhesion to the glass. The optimal initiator : rapeseed oil epoxide (ERO) : bitumen ratio was found to be 0.15:3:100; it allows obtaining bitumen with improved properties, in particular, adhesive properties increase by 2-3 times depending on the nature and content of the initiator. To improve the formula composite and evaluation of asphalt mixtures the additional researches will be conducted.
\end{abstract}

Keywords: bitumen, epoxide, rapeseed oil, modified bitumen, modification, adhesion.

\section{Introduction}

Various modifiers [1-11] for road bitumen have been developed and used to improve the properties of asphalt concrete pavements. Usually, they can be divided into polymers, adhesion promoters, fibers, waxes, rubber crumb, natural bitumen, and various chemical reagents (ferric chloride, anhydrides, amines, polyphosphoric acid, formaldehyde, and others). One of the most popular modifiers among the listed are polymers, which in their own turn, can also be divided into thermoplastics, thermoplastic elastomers, terpolymers (reactoplasts or thermosetting polymers), and latexes.

The concept of epoxy asphalt belongs to thermosetting modifiers. By the term "epoxy asphalt concrete" we mean various asphalt concrete mixtures containing epoxy compounds. However, even having good physical

\footnotetext{
${ }^{1}$ Lviv Polytechnic National University,

12, Bandera Str., 79013 Lviv, Ukraine

vstarchevskyy@gmail.com

(C) Starchevskyy V., Hrynchuk Yu., Matcipura P., Reutskyy V., 2021
}

and mechanical properties, epoxy asphalt is not widely used due to its high cost and technological features such as petroleum origin and toxicity of some hardeners.

Epoxy compounds can be polymerized in the presence of hardeners due to the presence of monomers or short-chain copolymers having an epoxy group at either end. Epoxy bituminous binder systems are able to form a continuous matrix of polymer chains with reactive functional groups and in the reaction of epoxy modifier with initiators. This process is called polymerization, which involves the formation, branching and cross-linking of epoxy polymer chains. During polymerization, the molecular weight increases, and a higher molecular weight is achieved when all the chains are interconnected in a network [12].

It is argued by Hrynchuk et al. [10] that the hardening of asphalt concrete is accompanied by polymerization reactions between the epoxy compound and the hardener and their cross-linking with the reaction structures of bitumen, which leads to changes in the properties of the obtained modified bituminous binder [13, 14]. Amine and amide hardeners for epoxy resins of petroleum origin or dibasic carboxylic acid can be used as initiators. The main disadvantage of the use of epoxy compounds in all studies is that modern epoxy resins made from petroleum raw materials are quite expensive and not environmentally friendly.

To confirm this, studies conducted to date have shown that epoxy-containing additives can dramatically change the properties of bitumen and asphalt concrete based on them [15-17]. The effect of such modification may be higher than in other types of modifiers. At the same time, epoxy asphalt concrete has increased strength and track resistance at elevated temperatures; high resistance to the formation of cracks at low temperatures; resistance to fuels and lubricants; and increase service life of roads by 3-4 times, as shown in [18-20]. Having a number of such advantages, epoxy asphalt concrete should be used for paving [21]. However modern epoxy resigns, obtained on the basis of oil, are highly priced and non-ecological. 
In view of the above, it becomes appropriate to study the ways of using epoxy compounds based on ecological plant origin, in particular rapeseed oil for the modification of road bitumen. At present, very little attention and effort has been paid in this area, and such a modifier is cheap to produce, affordable, environmentally friendly, and, moreover, is produced in sufficient quantities in Ukraine from renewable raw materials.

In addition, our previous studies discussed the feasibility of using epoxidized rapeseed oil as a modifier of road bitumen and asphalt concrete. We proposed to modify bitumen with the so-called bio-based epoxy rapeseed oil (BERO). By BERO we mean the use of a composition of rapeseed oil epoxide (ERO) obtained from renewable and ecological raw materials, rapeseed oil with organic initiators (hardeners) as a modifier of road bitumen [8-10].

Our study aims to create a new modification method for epoxy compounds of plant origin in the presence of initiators, which are able to obtain modified bitumen with known properties under different conditions. This will predict the behavior and methods of the process intensification. It is also necessary to choose a hardener that will improve the compatibility between the epoxy compound and bitumen and thus better physical and mechanical properties of the bituminous binder will be achieved.

Understanding the modification and curing mechanisms and their impact on the physical and mechanical properties of modified bitumen systems is an extremely important step in this work.

\section{Experimental}

\subsection{Initial Materials}

To obtain the modified bitumen, we used the oxidized road bitumen BND 70/100 produced by PJSC "Ukrtatnafta", Ukraine (Table 1).

For the oil bitumen modification we obtained epoxide of rapeseed oil using standard methodology [11]. The results are presented in Table 2.

We selected adipic acid (AA), maleic anhydride (MA) and polyethylene polyamine (PEPA) as the initiators in compositions with BERO.

\subsection{Experimental Procedure}

Our previous studies [10] contain information on the modification of bitumen and asphalt concrete with epoxidized rapeseed oil (ERO) on the basis of cheap ecological and renewable raw material - rapeseed oil (RO). The obtained results allow to characterize ERO as an effective modifier for petroleum road bitumen and asphalt concretes based on them.

Technological parameters for the modification of ERO bitumen were quite expensive and impractical. In particular, the results of qualitative characteristics of modified bitumen at the temperatures of $453-463 \mathrm{~K}$ and modification time over $5 \mathrm{~h}$ were obtained. From the idea of epoxy compounds and detailed analysis of the literature, we proposed to optimize this technology by adding initiators. The scheme that will initiate the polymerization of the epoxy component in bitumen and reduce the process temperature is given below (Fig. 1) [10, 22].

Table 1

Characteristics of road bitumen $70 / 100$

\begin{tabular}{|l|c|}
\hline \multicolumn{1}{|c|}{ Index } & Value \\
\hline Penetration at $298 \mathrm{~K}, \mathrm{~m} \cdot 10^{-4}(0.1 \mathrm{~mm})$ & 70 \\
\hline Softening point, $\mathrm{K}$ & 319 \\
\hline Ductility at $298 \mathrm{~K}, \mathrm{~m} \cdot 10^{-2}(\mathrm{~cm})$ & 100 \\
\hline Adhesion to glass, $\%$ & 33 \\
\hline Index of penetration & -15 \\
\hline Plasticity interval & 64 \\
\hline
\end{tabular}

Table 2

Characteristics of oil before and after epoxidizing

\begin{tabular}{|c|c|c|c|}
\hline Oil & Epoxy number (EN), $\%$ & Acid number (AN), g KOH/100g & Bromine number (BN), g Br/100g \\
\hline Rapeseed oil & 0.28 & 0.51 & 80.4 \\
\hline Epoxidized rapeseed oil & 6.73 & 0.44 & 1.8 \\
\hline
\end{tabular}




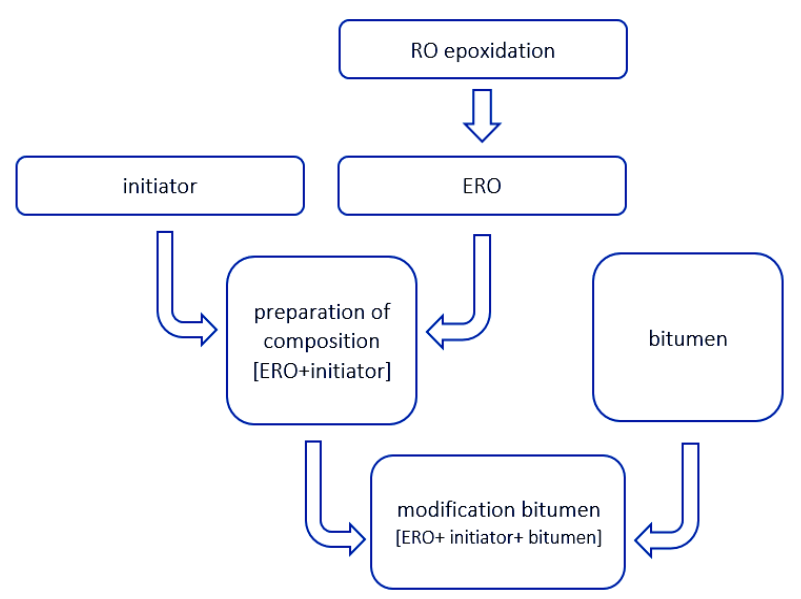

Fig. 1. Scheme of bitumen modification by green epoxy rapeseed oil

All preparations of bituminous compositions were carried out in a stirred reactor. To the heated bitumen a composition of BERO with different mass ratios of components was added, after which the composition was stirred for $2 \mathrm{~h}$ at the same temperature. The temperature was varied from 413 to $453 \mathrm{~K}$. The initiator content in $\mathrm{BERO}$, the amount of BERO and the modification temperature were changed to establish the dependences of bitumen physico-mechanical properties on the technological parameters. The obtained modified bitumen was evaluated by the softening temperature, penetration at $298 \mathrm{~K}$, ductility at $298 \mathrm{~K}$ and adhesion to glass [23-26].

\section{Results and Discussion}

\subsection{Effect of Initiator Content in ERO Composition on Bitumen Properties}

To determine the initiator : ERO optimal ratio, we studied its effect on the physico-mechanical properties of the samples at $433 \mathrm{~K}$. The BERO content in bitumen was $3 \mathrm{wt} \%$. The initiator content in the composition was varied from 1 to $20 \mathrm{wt} \%$. The MA content in the BERO composition was increased to $50 \%$ [22]. The results are shown in Tables 3-5.

Effect of the adipic acid (AA) concentration in the BERO composite on the properties of modified bitumen BND 70/100

\begin{tabular}{|c|c|c|c|}
\hline AA content in BERO, wt \% & Softening point, $\mathrm{K}$ & Adhesion to glass, $\%$ & Penetration at $298 \mathrm{~K}, \mathrm{~m} \cdot 10^{-4}$ \\
\hline 0 & 319.0 & 15.6 & 68 \\
\hline 3 & 319.0 & 29.6 & 77 \\
\hline 5 & 319.5 & 68.4 & 71 \\
\hline 7 & 319.0 & 75.4 & 77 \\
\hline 10 & 319.0 & 85.2 & 61 \\
\hline 13 & 320.0 & 87.5 & 62 \\
\hline 15 & 321.0 & 94.9 & 55 \\
\hline 20 & 321.0 & 93.3 & 55 \\
\hline
\end{tabular}

Table 4

Effect of the maleic anhydride (MA) concentration in the BERO composite on the properties of modified bitumen BND 70/100

\begin{tabular}{|c|c|c|c|}
\hline MA content in BERO, wt \% & Softening point, $\mathrm{K}$ & Adhesion to glass, $\%$ & Penetration at $298 \mathrm{~K}, \mathrm{~m} \cdot 10^{-4}$ \\
\hline 0 & 319.0 & 15.6 & 68 \\
\hline 3 & 320.0 & 17.9 & 61 \\
\hline 5 & 321.0 & 18.2 & 63 \\
\hline 7 & 321.0 & 23.6 & 62 \\
\hline 10 & 321.5 & 21.5 & 57 \\
\hline 13 & 321.0 & 20.9 & 55 \\
\hline 15 & 321.5 & 21.2 & 56 \\
\hline 17 & 322.0 & 21.9 & 51 \\
\hline 20 & 322.0 & 21.5 & 53 \\
\hline 40 & 322.0 & 21.9 & 39 \\
\hline 45 & 323.0 & 24.5 & 37 \\
\hline 50 & 322.0 & 23.2 & 37 \\
\hline
\end{tabular}


Effect of the polyethylene polyamine (PEPA) concentration in the BERO composite on the properties of modified bitumen BND 70/100

\begin{tabular}{|c|c|c|c|}
\hline $\begin{array}{c}\text { PEPA content } \\
\text { in BERO, wt } \%\end{array}$ & Softening point, K & Adhesion to glass, $\%$ & $\begin{array}{c}\text { Penetration at 298 K, } \\
\mathrm{m} \cdot 10^{-4}\end{array}$ \\
\hline 0 & 319.0 & 15,6 & 68 \\
\hline 3 & 318.0 & 85,6 & 71 \\
\hline 5 & 318.0 & 88,2 & 63 \\
\hline 7 & 319.0 & 91,3 & 68 \\
\hline 10 & 319.0 & 92,3 & 66 \\
\hline 13 & 320.0 & 95,5 & 66 \\
\hline 15 & 321.0 & 97,4 & 65 \\
\hline 17 & 319.0 & 97,5 & 65 \\
\hline
\end{tabular}

It is seen from Tables 3-5 that with increasing content of initiators in the composition from 1 to $20 \mathrm{wt} \%$ and up to $50 \mathrm{wt} \%$ in the case of maleic anhydride, the results were improved by $15-20 \%$ for all initiators. $15-$ $20 \mathrm{wt} \%$ of AA in BERO increases the softening temperature by $2 \mathrm{~K}$, reduces penetration by $5-10 \mathrm{~m} \cdot 10^{-4}$ and increases the adhesion to glass by 3-4 times in comparison with the original bitumen. Also, $15-20 \mathrm{wt} \%$ of MA in the composition allows to obtain modified bitumen with a fairly high softening temperature (323 K) and penetration of $55 \mathrm{~m} \cdot 10^{-4}$, but such an important index as adhesion has increased only twice. PEPA in the composition with ERO allows to obtain modified bitumen with the highest adhesion to glass (>98\%) while other indices are not changed. These results allow to choose the best ratio for the composition modification (initiator: $E R O=15: 85$ ). At other ratios, the physical and mechanical properties of modified bitumen are unsatisfactory, which makes it impractical to modify road bitumen at these ratios, or the content of the initiator is too high, which significantly increases the cost of the modifying system and is economically impractical.

Based on the obtained results, the optimal content of the initiator in the BERO composition was found to be $15 \mathrm{wt} \%$ at the modification temperature of $433 \mathrm{~K}$.

\subsection{Effect of Temperature}

\section{on the Properties of BERO Modified}

\section{Bitumen}

The modification process was performed in the temperature range of $413-453 \mathrm{~K}$. The BERO content in bitumen was $3 \mathrm{wt} \%$. The initiator content in the BERO composition was $15 \mathrm{wt} \%$. Modification time was $2 \mathrm{~h}$.

The results of the experiments are shown in Tables 6-8.
It is seen from the obtained results (Tables 4-6) that with the modification temperature increase from 413 to $453 \mathrm{~K}$ the physical and mechanical properties of bitumen are slightly improved. This trend is maintained for all BERO compositions, but only in the temperature range of $413-433 \mathrm{~K}$. Further increase in temperature to $453 \mathrm{~K}$ practically does not change the values achieved at $433 \mathrm{~K}$, which makes it impractical to carry out the modification at higher temperatures. So, the temperature of $433 \mathrm{~K}$ was found to be the optimum temperature of the modification process.

As can be seen from the results of research, with a constant value of EPO, an increase in the content of the initiator from 1 to $20 \mathrm{wt} \%$ allows to increase adhesion from $33 \%$ to $95 \%$ with virtually unchanged softening temperature. There are also slight changes in penetration when changing initiators in the process of bitumen modification.

These changes in bitumen quality with the changes in modification temperature and amount of initiator in the BERO composition indicates that ERO probably acts as a plasticizer, because in these cases with increasing content of initiator there is a gradual increase in physical and mechanical properties of modified bitumen. The level of growth of these indices increases with increasing content of initiators in the composite with ERO, but only to a certain extent, which may indicate the course of ERO chemical conversion with bitumen in the presence of the initiator. It is likely that this process is associated with the opening of ERO epoxy ring and the polymerization reaction between ERO and initiator, as well as their crosslinking with bitumen, which changes the properties of the final product.

This change in the adhesive properties of the BERO modified bitumen allows one to position such an additive as an adhesive. After all, BERO modified bitumen fully meets the requirements for bitumen modified with an adhesive additive [27]. 
Effect of modification temperature on the properties of BND 70/100 bitumen (AA is the initiator)

\begin{tabular}{|c|c|c|c|}
\hline Temperature, $\mathrm{K}$ & Softening point, $\mathrm{K}$ & Adhesion to glass, $\%$ & Penetration at $298 \mathrm{~K}, \mathrm{~m} \cdot 10^{-4}$ \\
\hline 413 & 320.0 & 93.9 & 93 \\
\hline 423 & 319.0 & 92.5 & 77 \\
\hline 433 & 321.0 & 94.9 & 62 \\
\hline 443 & 320.0 & 93.1 & 68 \\
\hline 453 & 321.0 & 93.9 & 72 \\
\hline
\end{tabular}

Effect of modification temperature on the properties of BND 70/100 bitumen (MA is the initiator)

\begin{tabular}{|c|c|c|c|}
\hline Temperature, $\mathrm{K}$ & Softening point, $\mathrm{K}$ & Adhesion to glass, $\%$ & Penetration at $298 \mathrm{~K}, \mathrm{~m} \cdot 10^{-4}$ \\
\hline 413 & 321.0 & 21.3 & 73 \\
\hline 423 & 320.0 & 21.3 & 65 \\
\hline 433 & 321.5 & 21.2 & 56 \\
\hline 443 & 321.0 & 21.6 & 55 \\
\hline 453 & 322.0 & 21.2 & 56 \\
\hline
\end{tabular}

Effect of modification temperature on the properties of BND 70/100 bitumen (PEPA is the initiator)

\begin{tabular}{|c|c|c|c|}
\hline Temperature, $\mathrm{K}$ & Softening point, $\mathrm{K}$ & Adhesion to glass, $\%$ & Penetration at $298 \mathrm{~K}, \mathrm{~m} \cdot 10^{-4}$ \\
\hline 413 & 320.0 & 97.2 & 83 \\
\hline 423 & 320.0 & 97.5 & 75 \\
\hline 433 & 321.0 & 97.4 & 66 \\
\hline 443 & 321.0 & 96.5 & 70 \\
\hline 453 & 322.0 & 95.6 & 73 \\
\hline
\end{tabular}

\section{Conclusions}

A new method of modifying bitumen with epoxy compounds of plant origin in the presence of initiators has been investigated. It is proposed to use adipic acid, maleic anhydride and polyethylene polyamine as initiators.

The positive effect of all investigated compositions on the qualitative properties of bitumen, namely adhesion, is shown.

The optimal content of the initiator in the composition of BERO was found to be $15 \mathrm{wt} \%$. This amount allows to increase the adhesion index by 3-4 times. The dependence of physical and mechanical properties of BERO modified bitumen on the modification temperature was established. The temperature of $433 \mathrm{~K}$ can be taken as the optimum temperature of the modification process because at this temperature it is possible to achieve good results, while further increase in temperature does not lead to significant changes and, therefore, is economically impractical.

\section{References}

[1] Airey G.: Fuel, 2003, 82, 1709. https://doi.org/10.1016/S00162361(03)00146-7
[2] Demchuk Y., Sidun I., Gunka V. et al.: Chem. Chem. Technol., 2018, 12, 456. https://doi.org/10.23939/chcht12.04.456

[3] Zhang W., Ding L., Jia Z.: Appl. Sci., 2018, 8, 457. https://doi.org/10.3390/app8030457

[4] Pyshyev S., Demchuk Y., Gunka V. et al.: Chem. Chem. Technol. 2019, 13, 212-217. https://doi.org/10.23939/chcht13.02.212

[5] Gunka V., Demchuk Yu., Pyshyev S. et al.: Petrol. Coal, 2018, 60, 1199.

[6] Gunka V., Sidun I., Solodkyy S., Vytrykush N.: Lecture Notes in Civil Eng. Proceedings of CEE 2019. Springer 2019, 47, 420.

[7] Wei J., Zhang Y.: J. Test. Eval., 2012, 40, 1169.

https://doi.org/10.1520/JTE20120136

[8] Hrynchuk Y., Sidun I., Gunka V. et al.: Petrol. Coal, 2019, 61, 836.

[9] Nykypanchuk M., Hrynchuk Y., Olchovyk M.: Chem. Chem. Technol. 2013, 7, 467. https://doi.org/10.23939/chcht07.04.467

[10] Hrynchuk Y., Sidun I., Gunka V. et al.: Petrol. Coal, 2020, 62, 836.

[11] Demchuk Y., Gunka V., Pyshyev S. et al.: Chem. Chem. Technol., 2020, 14, 251. https://doi.org/10.23939/chcht14.02.251

[12] Martynyuk M.: Visnyk Prykarpat. Nats. Univ. im. Vasylya Stefanyka, 2014, V, 115.

http://nbuv.gov.ua/UJRN/vpnu chem $2014 \quad 1816$.

[13] Chemco System Co., 2012, "Epoxy Asphalt for Orthotropic Steel Bridge Decks," http://www.chemcosystems.com/epoxy.html (Last accessed June 10, 2011).

[14] Apostolidis P., Liu X., van de Ven M. et al.: J. Transport. Res. Board., 2019, 2673, 551. https://doi.org/10.1177/0361198119835530 [15] Yu L.: Highway, 2004, 3, 56. 
[16] Kang Y., Chen Z., Jiao Z., Huang W.: J. Appl. Polym. Sci., 2010, 116, 1678. https://doi.org/10.1002/app.31563

[17] Pan L., Wang Y., Wang C. et al.: Thermoset. Resin, 2011, 26, 33. [18] Zhou X., Wu S., Liu G., Pan P.: Materials and Structures. Nanjing. 2016, 49, 241.

https://ink.springer.com/article/10.1617/s11527-014-0491-4 [19] Ivashkiv O, Astakhova O., Shyshchak O. et al.: Chem. Chem. Technol., 2015, 9, 69. https://doi.org/10.23939/chcht09.01.069 [20] Bratychak M., Brostow W., Grynyshyn O., Shyshchak O.: Mater. Res. Innovat., 2003, 7, 167. https://doi.org/10.1007/s10019-003-0243-5 [21] Alabaster D., Herrington P., Waters J.: J. Acoustic. Soc. Am., 2012, 131, 3225. https://doi.org/10.1121/1.4708028

[22] Al Fuhaid A., Lu Q., Luo S.: J. Mater. Civil Eng., 2018, 30, 256. https://doi.org/10.1061/(ASCE)MT.1943-5533.0002383

[23] EN 1427. European Standard. Bitumen and bituminous binders. Determination of the softening point. Ring and Ball method.

$\lceil 24\rceil$ EN 1426. European Standard. Bitumen and bituminous binders. Methods of tests for petroleum and its products. Determination of needle penetration.

[25] EN 13587. Bitumen and bituminous binders. Determination of the tensile properties of bituminous binders by the tensile test method. $\lceil 26\rceil$ Pyrig Yan, Galkin A.: Bull. Kharkov Nat. Automobile and Highway Univ., 2019, 1, 202. https://doi.org/10.30977/BUL.22195548.2019.86.1.202

[27] http://online.budstandart.com/ua/catalog/doc-page?id_doc=27298

Received: December 03, 2019 / Revised: December 22, 2019 / Accepted: February 12, 2020

\section{ВПЛИВ ІНІЦІАТОРІВ \\ НА АДГЕЗІЙНІ ВЛАСТИВОСТІ БІТУМІВ, МОДИФІКОВАНИХ ЕПОКСИДОМ РОСЛИННОГО ПОХОДЖЕННЯ}

Анотація. Запропоновано модифікування бітумного в'яжучого екологічною епоксидованою ріпаковою олією (BERO) в присутності ініціатора (затверджувача). Як інічіатор використано адипінову кислоту (АA), малеӥновий ангідрид (МА) та поліетиленполіамін (РЕРА). Встановлено вплив температури модифікування та співвідношення ініціатор : епоксид ріпакової олії (ЕRO) : бітум, а також природи інічіатора на властивості модифікованого бітуму. Оиінено такі якісні показники бітуму, як температура розм'якшення, пенетрація, дуктильність та адгезія до скла. Встановлено оптимальне співвідношення інічіатор : ERO : бітум =0,15:3:100, за якого одержують бітум з покращеними властивостями, зокрема адгезійні властивості підвищуються в 2-3 рази, в залежності від природи і вмісту ініціатора. Для вдосконалення формули композиту та оцінки асфальтобетонних сумішей будуть проведені подальші дослідження.

Ключові слова: бітум, епоксид, ріпакова олія, модифікований бітум, модифікаиія, епоксидована ріпакова олія, адгезія. 